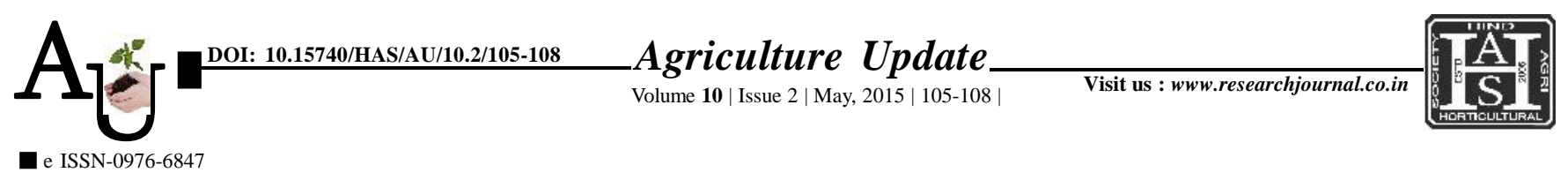

\title{
Research Article: Training need of agricultural input dealers for transfer of technology
}

P.S. SHELAKE, N.J. CHIKHALE*, A.N. DESHMUKH AND S.R. BHOSALE

Article Chronicle:

Received :

21.08.2014;

Revised :

08.03.2015;

Accepted :

22.03.2015

KEY WoRDS:

Training need, Agricultural input dealers, Transfer of technology

Author for correspondence :

\section{N.J. CHIKHALE}

Shri Shivaji Agriculture College, AMRAVATI (M.S.) INDIA

See end of the article for authors' affiliations
SUMMARY : The present study on training need of agricultural input dealers for transfer of technology was conducted in the year 2013-14 in Amravati district. For this study 80 dealers were purposively selected from five tahsils of district with the help of proportionate sampling method. The data were collected with the help of structured interview schedule. Personal interview technique was used for data collection. It was observed that majority of the agricultural input dealers were 'middle' age, with 'medium' experience in fertilizer dealing, information seeking behaviour, risk orientation, economic motivation and cosmopoliteness. Majority of the respondents were 'graduate' and all had 'input dealing' as their major occupation and 'medium' annual income. All of the agricultural input dealers had "not received" training on various aspects related to fertilizers, seeds, insecticides, pesticides and implements. Majority of the agricultural input dealers had supplied 'chemical fertilizers', 'seeds' and 'pesticides'. Most $(61.25 \%)$ of the respondents had 'fair' advisory service. Majority $(100.00 \%)$ of the agricultural input dealers provided the information about different improved varieties of crops, fertilizers and their doses, time and method of application, control of pest and disease of crops and improved methods of irrigation, soil testing, improved technology etc. In respect of training needs, agricultural input dealers had expressed 'high' training needs on 'micro nutrient fertilizers' followed by 'integrated nutrient management', 'improved varieties and hybrids of different crops', 'types of improved sprayers and dusters', 'information communication technology', 'efficient use of information technology', 'business management' and 'government rules and regulation'. 'Economical problem', 'availability of labours', 'lack of organization of dealers', 'late for getting rupees from farmers', were the major constraints faced by them.

How to cite this article : Shelake, P.S., Chikhale, N.J., Deshmukh, A.N. and Bhosale, S.R. (2015). Training need of agricultural input dealers for transfer of technology. Agric. Update, 10(2): 105-108. 